\title{
Syntheses, Crystal Structures and Antimicrobial Property of Schiff Base Copper(II) Complexes
}

\author{
Shun-Feng Yu, Xiao-Yang Qiu* and Shu-Juan Liu* \\ College of Science and Technology, Ningbo University, Ningbo 315212, P. R. China \\ *Corresponding author: E-mail: xiaoyang_qiu@126.com (Xiao-Yang Qiu), \\ lsj_578@163.com (Shu-Juan Liu)
}

Received: 08-06-2020

\begin{abstract}
Four new copper(II) complexes, $\left[\mathrm{CuL}^{1}\left(\mu_{1,1}-\mathrm{N}_{3}\right)\right]_{\mathrm{n}}(\mathbf{1}),\left[\mathrm{CuL}^{1}\left(\mu_{1,3}-\mathrm{NCS}\right)\right]_{\mathrm{n}}(\mathbf{2}),\left[\mathrm{Cu}\left(\mathrm{HL}^{2}\right)_{2}\right](\mathrm{SCN})_{2}(\mathbf{3})$ and $\left[\mathrm{Cu}\left(\mathrm{L}^{2}\right)_{2}\right](\mathbf{4})$, where $\mathrm{L}^{1}$ and $\mathrm{L}^{2}$ are 2-((2-(dimethylamino)ethylimino)methyl-4,6-difluorophenolate and 2,4-difluoro-6-((3-morpholinopropylimino)methyl)phenolate, respectively, and $\mathrm{HL}^{2}$ is 2 -((2-(dimethylammonio)ethylimino)methyl-4,6-difluorophenolate, were synthesized and characterized by elemental analysis, IR and UV-vis spectroscopy. The structures for the complexes were further confirmed by single crystal X-ray structure determination. Complexes $\mathbf{1}$ and $\mathbf{2}$ are polymeric copper(II) complexes, with the $\mathrm{Cu}$ atoms in square pyramidal coordination. Complexes $\mathbf{3}$ and $\mathbf{4}$ are mononuclear copper(II) complexes, with the $\mathrm{Cu}$ atoms in square planar coordination. The complexes were assayed for their antimicrobial properties.
\end{abstract}

Keywords: Schiff base; copper complex; crystal structure; antimicrobial property

\section{Introduction}

Schiff base compounds and their metal complexes have attracted much attention due to their interesting biological aspects like antibacterial, ${ }^{1}$ antifungal, ${ }^{2}$ and antitumor. ${ }^{3}$ It has been proved that the compounds with electron-withdrawing substituent groups can enhance their antimicrobial ability. ${ }^{4}$ Rai et al. reported some compounds with fluoro, chloro, bromo, and iodo-substituted groups, and their remarkable antimicrobial property. ${ }^{5}$ Schiff base complexes of copper have potential antibacterial property. ${ }^{6}$ Recently, our research group has reported some Schiff base complexes with biological properties. ${ }^{7}$ In pursuit of new Schiff base complexes with potential antimicrobial property, in this work, four new copper(II) complexes, $\left[\mathrm{CuL}^{1}\left(\mu_{1,1}-\mathrm{N}_{3}\right)\right]_{\mathrm{n}}(\mathbf{1}),\left[\mathrm{CuL}^{1}\left(\mu_{1,3}-\mathrm{NCS}\right)\right]_{\mathrm{n}}(\mathbf{2}),\left[\mathrm{Cu}\left(\mathrm{HL}^{2}\right)_{2}\right]$ $(\mathrm{SCN})_{2}(3)$ and $\left[\mathrm{Cu}\left(\mathrm{L}^{2}\right)_{2}\right](4)$, where $\mathrm{L}^{1}$ and $\mathrm{L}^{2}$ are 2 - ( $(2$ - $(\mathrm{di}$ methylamino)ethylimino)methyl-4,6-diluorophenolate and 2,4-difluoro-6-((3-morpholinopropylimino)methyl) phenolate, respectively, and $\mathrm{HL}^{2}$ is 2-( 2 -(dimethylammonio)ethylimino)methyl-4,6-diluorophenolate, and their antimicrobial properties are present.

\section{Experimental}

\section{1. Materials and Methods}

3,5-Difluorosalicylaldehyde, $N, N$-dimethylethane-1, 2-diamine, $\mathrm{N}$-(3-aminopropyl)morpholine, copper bro- mide, ammonium thiocyanate and sodium azide were obtained from Sigma-Aldrich. All other chemicals were commercial obtained from Xiya Chemical Co. Ltd. Elemental analyses of $\mathrm{C}, \mathrm{H}$ and $\mathrm{N}$ were carried out in a Perkin-Elmer automated model 2400 Series II CHNS/O analyzer. The molar conductivity was determined using DDS11A conductor device. FT-IR spectra were obtained on a Perkin-Elmer 377 FT-IR spectrometer with samples prepared as $\mathrm{KBr}$ pellets. UV-Vis spectra were obtained on a Lambda 35 spectrometer. Single crystal structural X-ray diffraction was carried out on a Bruker APEX II CCD diffractometer.

Caution! Because of their explosive character, sodium azide and the complexes containing azide ligand should be handled with care and in very low amounts.

\section{2. Synthesis of Complex 1}

3,5-Difluorosalicylaldehyde $(0.10 \mathrm{mmol}, 16 \mathrm{mg})$, $\mathrm{N}, \mathrm{N}$-dimethylethane-1,2-diamine $(0.10 \mathrm{mmol}, 8.8 \mathrm{mg})$, sodium azide $(0.10 \mathrm{mmol}, 6.5 \mathrm{mg})$ and copper bromide $(0.10 \mathrm{mmol}, 22 \mathrm{mg})$ were mixed in methanol $(15 \mathrm{~mL})$ to give a clear blue solution. Block blue single crystals of the complex, suitable for X-ray diffraction, were grown from the solution upon slowly evaporation within five days. The crystals were isolated by filtration. Yield $37 \%$. Anal. calc. for $\mathrm{C}_{11} \mathrm{H}_{13} \mathrm{CuF}_{2} \mathrm{~N}_{5} \mathrm{O}: \mathrm{C}, 39.70 ; \mathrm{H}, 3.94 ; \mathrm{N}, 21.04$; found: $\mathrm{C}$, 39.57; $\mathrm{H}, 4.03 ; \mathrm{N}, 20.89 \%$. IR data $\left(\mathrm{cm}^{-1}\right): 2045$ (s), 1637 
(s), $1461(\mathrm{~s}), 1255(\mathrm{~m})$. UV-Vis data $\left(\mathrm{MeOH}, \lambda_{\max }, \mathrm{nm}\right)$ : $215,265,376,572 . \Lambda_{\mathrm{M}}\left(10^{-3} \mathrm{M}\right.$ in methanol): $45 \Omega^{-1} \mathrm{~cm}^{2}$ $\mathrm{mol}^{-1}$.

\section{3. Synthesis of Complex 2}

The complex was prepared with similar method as that described for complex 1, but with sodium azide replaced with ammonium thiocyanate $(0.10 \mathrm{mmol}, 7.6 \mathrm{mg})$. Block blue single crystals of the complex, suitable for X-ray diffraction, were grown from the solution upon slowly evaporation within a week. The crystals were isolated by filtration. Yield $41 \%$. Anal. calc. for $\mathrm{C}_{12} \mathrm{H}_{13} \mathrm{CuF}_{2} \mathrm{~N}_{3} \mathrm{OS}$ : C, 41.31; H, 3.76; N, 12.05; found: C, 41.13; H, 3.92; N, 12.21\%. IR data $\left(\mathrm{cm}^{-1}\right): 2094(\mathrm{~s}), 1636(\mathrm{~s}), 1462(\mathrm{~s}), 1257$ (m). UV-Vis data $\left(\mathrm{MeOH}, \lambda_{\max }, \mathrm{nm}\right): 215,265,380,575$. $\Lambda_{\mathrm{M}}\left(10^{-3} \mathrm{M}\right.$ in methanol): $42 \Omega^{-1} \mathrm{~cm}^{2} \mathrm{~mol}^{-1}$.

\section{4. Synthesis of Complex 3}

3,5-Difluorosalicylaldehyde $(0.10 \mathrm{mmol}, 16 \mathrm{mg})$, $\mathrm{N}$-(3-aminopropyl)morpholine $(0.10 \mathrm{mmol}, 14 \mathrm{mg})$, ammonium thiocyanate $(0.10 \mathrm{mmol}, 7.6 \mathrm{mg})$ and copper bromide $(0.10 \mathrm{mmol}, 22 \mathrm{mg})$ were mixed in methanol $(15 \mathrm{~mL})$ to give a clear blue solution. Block blue single crystals of the complex, suitable for X-ray diffraction, were grown from the solution upon slowly evaporation within three days. The crystals were isolated by filtration. Yield $27 \%$.
Anal. calc. for $\mathrm{C}_{30} \mathrm{H}_{36} \mathrm{CuF}_{4} \mathrm{~N}_{6} \mathrm{O}_{4} \mathrm{~S}_{2}: \mathrm{C}, 48.15 ; \mathrm{H}, 4.85 ; \mathrm{N}$, 11.23; found: $\mathrm{C}, 48.30 ; \mathrm{H}, 4.92 ; \mathrm{N}, 11.11 \%$. IR data $\left(\mathrm{cm}^{-1}\right)$ : 2056 (s), 1626 (s), 1480 (m), 1265 (m). UV-Vis data $\left(\mathrm{MeOH}, \lambda_{\max }, \mathrm{nm}\right): 210,270,362,587 . \Lambda_{\mathrm{M}}\left(10^{-3} \mathrm{M}\right.$ in methanol): $182 \Omega^{-1} \mathrm{~cm}^{2} \mathrm{~mol}^{-1}$.

\section{5. Synthesis of Complex 4}

The complex was prepared with similar method as that described for complex 3 , but with ammonium thiocyanate replaced with sodium azide $(0.10 \mathrm{mmol}, 6.5 \mathrm{mg})$. Block blue single crystals of the complex, suitable for X-ray diffraction, were grown from the solution upon slowly evaporation within a week. The crystals were isolated by filtration. Yield 39\%. Anal. calc. for $\mathrm{C}_{28} \mathrm{H}_{34} \mathrm{CuF}_{4} \mathrm{~N}_{4} \mathrm{O}_{4}$ : C, 53.37; H, 5.44; N, 8.89; found: C, 53.23; H, 5.52; N, 8.75\%. IR data $\left(\mathrm{cm}^{-1}\right)$ : $1628(\mathrm{~s}), 1472(\mathrm{~s}), 1268(\mathrm{~m})$. UV-Vis data $\left(\mathrm{MeOH}, \lambda_{\max }, \mathrm{nm}\right): 210,270,360,595 . \Lambda_{\mathrm{M}}\left(10^{-3} \mathrm{M}\right.$ in methanol): $36 \Omega^{-1} \mathrm{~cm}^{2} \mathrm{~mol}^{-1}$.

\section{6. X-ray Crystallography}

$\mathrm{X}$-ray diffraction was carried out at a Bruker APEX II CCD area diffractometer equipped with MoKa radiation $(\lambda=0.71073 \AA)$. The collected data were reduced with SAINT, ${ }^{8}$ and multi-scan absorption correction was performed using SADABS. ${ }^{9}$ The structures of the complexes were solved by direct method, and refined against $F^{2}$ by

Table 1. Crystallographic and refinement data for the complexes

\begin{tabular}{|c|c|c|c|c|}
\hline Complex & 1 & 2 & 3 & 4 \\
\hline Formula & $\mathrm{C}_{11} \mathrm{H}_{13} \mathrm{CuF}_{2} \mathrm{~N}_{5} \mathrm{O}$ & $\mathrm{C}_{12} \mathrm{H}_{13} \mathrm{CuF}_{2} \mathrm{~N}_{3} \mathrm{OS}$ & $\mathrm{C}_{30} \mathrm{H}_{36} \mathrm{CuF}_{4} \mathrm{~N}_{6} \mathrm{O}_{4} \mathrm{~S}_{2}$ & $\mathrm{C}_{28} \mathrm{H}_{34} \mathrm{CuF}_{4} \mathrm{~N}_{4} \mathrm{O}_{4}$ \\
\hline Formula weight & 332.80 & 348.85 & 748.31 & 630.13 \\
\hline$T(\mathrm{~K})$ & $298(2)$ & $298(2)$ & $298(2)$ & $298(2)$ \\
\hline Crystal system & Monoclinic & Monoclinic & Triclinic & Triclinic \\
\hline Space group & $P 2_{1} / c$ & $P 2_{1} / c$ & $P-1$ & $P-1$ \\
\hline$a(\AA)$ & $10.074(1)$ & $16.352(1)$ & $6.4118(8)$ & $4.731(1)$ \\
\hline$b(\AA)$ & $6.531(1)$ & $7.563(1)$ & $7.465(1)$ & $11.399(1)$ \\
\hline$c(\AA)$ & $20.322(1)$ & $11.761(1)$ & $17.532(1)$ & $13.749(1)$ \\
\hline$\alpha\left({ }^{\circ}\right)$ & 90 & 90 & $93.867(1)$ & $68.109(1)$ \\
\hline$\beta\left({ }^{\circ}\right)$ & $101.559(1)$ & $103.849(1)$ & $100.024(1)$ & $81.436(1)$ \\
\hline$\gamma\left({ }^{\circ}\right)$ & 90 & 90 & $90.778(1)$ & $84.849(1)$ \\
\hline$V\left(\AA^{3}\right)$ & $1310.0(3)$ & $1412.2(3)$ & $824.2(2)$ & $679.9(2)$ \\
\hline$Z$ & 4 & 4 & 1 & 1 \\
\hline$D_{\text {calc }}\left(\mathrm{g} \mathrm{cm}^{-3}\right)$ & 1.687 & 1.641 & 1.508 & 1.539 \\
\hline$\mu(\mathrm{Mo} \mathrm{Ka})\left(\mathrm{mm}^{-1}\right)$ & 1.694 & 1.714 & 0.857 & 0.873 \\
\hline$F(000)$ & 676 & 708 & 387 & 327 \\
\hline Measured reflections & 7376 & 8002 & 4867 & 10251 \\
\hline Unique reflections & 2429 & 2600 & 3040 & 2529 \\
\hline Observed reflections $(I \geq 2 \sigma(I))$ & 1790 & 1625 & 2396 & 1913 \\
\hline Parameters & 183 & 183 & 214 & 187 \\
\hline Restraints & 0 & 0 & 0 & 0 \\
\hline GOOF & 1.005 & 1.001 & 1.129 & 1.000 \\
\hline$R_{1}, w R_{2}[I \geq 2 \sigma(I)]^{a}$ & $0.0320,0.0667$ & $0.0581,0.1471$ & $0.0491,0.1290$ & $0.0502,0.1261$ \\
\hline$R_{1}, w R_{2}(\text { all data })^{a}$ & $0.0552,0.0736$ & $0.0981,0.1822$ & $0.0714,0.1689$ & $0.0719,0.1381$ \\
\hline
\end{tabular}

\footnotetext{
${ }^{\mathrm{a}} R_{1}=\Sigma|| F_{\mathrm{o}}|-| F_{\mathrm{c}}|| / \Sigma\left|F_{\mathrm{o}}\right|, w R_{2}=\left\{\Sigma\left[w\left(F_{\mathrm{o}}{ }^{2}-F_{\mathrm{c}}{ }^{2}\right)^{2}\right] / \Sigma\left[w\left(F_{\mathrm{o}}{ }^{2}\right)^{2}\right]\right\}^{1 / 2}$
} 
full-matrix least-squares method using SHELXTL. ${ }^{10}$ All of the non-hydrogen atoms were refined anisotropically. The hydrogen atoms were placed in calculated positions and constrained to ride on their parent atoms. The crystallographic data and refinement parameters for the complexes are listed in Table 1. Selected bond lengths and angles are listed in Table 2.

Table 2. Selected bond distances $(\AA)$ and angles $\left(^{\circ}\right)$ for the complexes

\begin{tabular}{llll}
\hline $\mathbf{1}$ & & & \\
\hline $\mathrm{Cu} 1-\mathrm{O} 1$ & $1.9224(17)$ & $\mathrm{Cu} 1-\mathrm{N} 1$ & $1.963(2)$ \\
$\mathrm{Cu} 1-\mathrm{N} 2$ & $2.075(2)$ & $\mathrm{Cu} 1-\mathrm{N} 3$ & $1.986(2)$ \\
$\mathrm{O} 1-\mathrm{Cu} 1-\mathrm{N} 1$ & $92.61(8)$ & $\mathrm{O} 1-\mathrm{Cu} 1-\mathrm{N} 3$ & $89.49(8)$ \\
$\mathrm{N} 1-\mathrm{Cu} 1-\mathrm{N} 3$ & $170.79(11)$ & $\mathrm{O} 1-\mathrm{Cu} 1-\mathrm{N} 2$ & $176.46(8)$ \\
$\mathrm{N} 1-\mathrm{Cu} 1-\mathrm{N} 2$ & $83.98(9)$ & $\mathrm{N} 3-\mathrm{Cu} 1-\mathrm{N} 2$ & $93.74(9)$ \\
\hline $\mathbf{2}$ & & & \\
\hline $\mathrm{Cu} 1-\mathrm{O} 1$ & $1.898(4)$ & $\mathrm{Cu} 1-\mathrm{N} 1$ & $1.933(5)$ \\
$\mathrm{Cu} 1-\mathrm{N} 2$ & $2.076(6)$ & $\mathrm{Cu} 1-\mathrm{N} 3$ & $1.944(4)$ \\
$\mathrm{O} 1-\mathrm{Cu} 1-\mathrm{N} 3$ & $90.9(2)$ & $\mathrm{O} 1-\mathrm{Cu} 1-\mathrm{N} 1$ & $92.1(2)$ \\
$\mathrm{N} 3-\mathrm{Cu} 1-\mathrm{N} 1$ & $168.9(2)$ & $\mathrm{O} 1-\mathrm{Cu} 1-\mathrm{N} 2$ & $171.5(2)$ \\
$\mathrm{N} 3-\mathrm{Cu} 1-\mathrm{N} 2$ & $91.1(2)$ & $\mathrm{N} 1-\mathrm{Cu} 1-\mathrm{N} 2$ & $84.4(2)$ \\
\hline $\mathbf{3}$ & & & \\
\hline $\mathrm{Cu} 1-\mathrm{O} 1$ & $1.892(3)$ & $\mathrm{Cu} 1-\mathrm{N} 1$ & $2.013(3)$ \\
$\mathrm{O} 1-\mathrm{Cu} 1-\mathrm{O} 1 \mathrm{~A}$ & 180 & $\mathrm{O} 1-\mathrm{Cu} 1-\mathrm{N} 1$ & $92.28(12)$ \\
$\mathrm{O} 1-\mathrm{Cu} 1-\mathrm{N} 1 \mathrm{~A}$ & $87.72(12)$ & $\mathrm{N} 1-\mathrm{Cu} 1-\mathrm{N} 1 \mathrm{~A}$ & 180 \\
\hline $\mathbf{4}$ & & & \\
\hline $\mathrm{Cu} 1-\mathrm{O} 1$ & $1.875(2)$ & $\mathrm{Cu} 1-\mathrm{N} 1$ & $2.007(3)$ \\
$\mathrm{O} 1-\mathrm{Cu} 1-\mathrm{O} 1 \mathrm{~A}$ & 180 & $\mathrm{O} 1-\mathrm{Cu} 1-\mathrm{N} 1 \mathrm{~A}$ & $88.06(10)$ \\
$\mathrm{O} 1-\mathrm{Cu} 1-\mathrm{N} 1$ & $91.94(10)$ & $\mathrm{N} 1-\mathrm{Cu} 1-\mathrm{N} 1 \mathrm{~A}$ & 180 \\
\hline
\end{tabular}

Symmetry code for A: $1-x, 1-y, 1-z$.

\section{7. Antimicrobial Assay}

The antibacterial property of the complexes was tested against Bacillus subtilis, Staphylococcus aureus, Escherichia coli, and Pseudomonas fluorescence using $\mathrm{MH}$ (Mueller-Hinton) medium. The antifungal activities of the compounds were tested against Candida albicans and Aspergillus niger using RPMI-1640 medium. The MIC values of the tested compounds were determined by a colorimetric method using the dye MTT. ${ }^{11}$ A stock solution of the compound $\left(150 \mu \mathrm{g} \mathrm{mL}^{-1}\right)$ in DMSO was prepared and graded quantities $\left(75 \mu \mathrm{g} \mathrm{mL}^{-1}, 37.5 \mu \mathrm{g} \mathrm{mL}^{-1}, 18.8 \mu \mathrm{g} \mathrm{mL}^{-1}\right.$, $9.4 \mu \mathrm{g} \mathrm{mL} L^{-1}, 4.7 \mu \mathrm{g} \mathrm{mL}^{-1}, 2.3 \mu \mathrm{g} \mathrm{mL}^{-1}, 1.2 \mu \mathrm{g} \mathrm{mL}^{-1}, 0.59 \mu \mathrm{g}$ $\mathrm{mL}^{-1}$ ) were incorporated in specified quantity of the corresponding sterilized liquid medium. A specified quantity of the medium containing the compound was poured into micro-titration plates. Suspension of the microorganism was prepared to contain approximately $1.0 \times 10^{5} \mathrm{cfu} \mathrm{mL}^{-1}$ and applied to microtitration plates with serially diluted compounds in DMSO to be tested and incubated at $37^{\circ} \mathrm{C}$ for $24 \mathrm{~h}$ and $48 \mathrm{~h}$ for bacteria and fungi, respectively. Then the MIC values were visually determined on each of the microtitration plates, $50 \mu \mathrm{L}$ of PBS (phosphate buffered saline $0.01 \mathrm{~mol} \mathrm{~L}^{-1}, \mathrm{pH}=7.4$ ) containing $2 \mathrm{mg}$ of MTT mL $\mathrm{MT}^{-1}$ was added to each well. Incubation was continued at room temperature for $4-5 \mathrm{~h}$. The content of each well was removed and $100 \mu \mathrm{L}$ of isopropanol containing $5 \% 1 \mathrm{~mol} \mathrm{~L}^{-1}$ $\mathrm{HCl}$ was added to extract the dye. After $12 \mathrm{~h}$ of incubation at room temperature, the optical density was measured with a microplate reader at $550 \mathrm{~nm}$.

\section{Results and Discussion}

\section{1. Synthesis and Characterization}

The complexes were readily prepared by the reaction of equimolar quantities of 3,5-difluorosalicylaldehyde, $N, N$-dimethylethane-1,2-diamine or $N$-(3-aminopropyl)morpholine, sodium azide or ammonium thiocyanate, and copper bromide in methanol. Single crystals of the complexes were obtained by slow evaporation of their methanolic solution. The azide and thiocyanate coordinate to the $\mathrm{Cu}$ atoms in complexes $\mathbf{1}$ and 2, respectively. However, the thiocyanate acts as a counteranion in complex 3 , and the azide is absent in complex 4 . Without sodium azide, complex 4 can also be obtained by the reaction of equimolar quantities of 3,5-difluorosalicylaldehyde, $\mathrm{N}$-(3-aminopropyl)morpholine, and copper bromide in methanol. Elemental analyses of the complexes are in accordance with the molecular structures determined by the single crystal X-ray analysis. Molar conductivity for $10^{-3} \mathrm{~mol} \mathrm{~L}^{-1}$ sample/methanol solutions for ionic electrolytes at $25{ }^{\circ} \mathrm{C}$ indicates the non-electrolytic nature of complexes 1, 2 and 4, and 1:2 electrolytic nature of complex. ${ }^{12}$

\section{2. Spectroscopic Studies}

The typical and strong absorptions at 1626-1637 $\mathrm{cm}^{-1}$ of the complexes are generated by the vibrations of the $\mathrm{C}=\mathrm{N}$ bonds, indicating the formation of the Schiff bases from the condensation reaction of the 3,5-difluorosalicylaldehyde and the amines during the coordination. The intense absorption at $2045 \mathrm{~cm}^{-1}$ for complex 1 is attributed to the stretching vibration of the azide, ${ }^{13}$ and those at 2094 $\mathrm{cm}^{-1}$ for complex 2 and $2056 \mathrm{~cm}^{-1}$ for complex 3 are assigned to the stretching vibrations of $\mathrm{CN}$ bond in thiocyanate. The difference of the absorption bands of the thiocyanate groups, indicates different modes in the complexes. The thiocyanate in complex 2 coordinates to the $\mathrm{Cu}$ atom, while that in complex $\mathbf{3}$ is free. ${ }^{14}$

In the UV-Vis spectra of the complexes, the bands at 360-380 $\mathrm{nm}$ are attributed to the azomethine chromophore $\pi \rightarrow \pi^{*}$ transition. ${ }^{15}$ The bands at higher energies (210-215 and 265-270 nm) are associated with the benzene $\pi \rightarrow \pi^{*}$ transition. ${ }^{15}$ The weak and less well-defined broad bands found at $570-600 \mathrm{~nm}$ are assigned to the $d-d$ transitions. ${ }^{16}$ 


\section{3. Structure Description of Complex 1}

Molecular structure of the end-on azido bridged polymeric copper complex $\mathbf{1}$ is shown in Figure 1. The asymmetric unit of the complex contains a $\left[\mathrm{CuL}^{1}\left(\mathrm{~N}_{3}\right)\right]$ unit. The $\mathrm{Cu}$ atom is coordinated in a square pyramidal geometry, with the phenolate $\mathrm{O} 1$, imino $\mathrm{N} 1$, amino $\mathrm{N} 2$ atoms of the Schiff base ligand $\mathrm{L}^{1}$, and the azido $\mathrm{N} 3$ atom defining the basal plane, and with the azido N3A atom located at the apical position. The Schiff base ligand, acts as a tridentate ligand, chelate the $\mathrm{Cu}$ atom by generating one five and one six-membered rings with bite angles of $83.98(9)^{\circ}$ and $92.61(8)^{\circ}$, respectively. The displacement of the $\mathrm{Cu}$ atom from the plane defined by the four basal donor atoms toward the apical azido $\mathrm{N}$ atom by $0.087(2) \AA$. The azide ligand bridges $\mathrm{Cu}$ atoms with an end-on bridging mode, generating a $\mathrm{Cu} \cdots \mathrm{Cu}$ distance of 4.156(3) $\AA$. The bond lengths and angles in the square pyramidal coordination are similar to those in the reported azido bridged Schiff base copper complexes. ${ }^{17}$ In the crystal structure of the complex, the $\left[\mathrm{CuL}^{1}\right]$ units are linked by the azide bridges, to form one-dimensional chains along the $b$ axis (Figure 2).

\section{4. Structure Description of Complex 2}

Molecular structure of the end-to-end thiocyanato bridged polymeric copper complex $\mathbf{2}$ is shown in Figure 3.

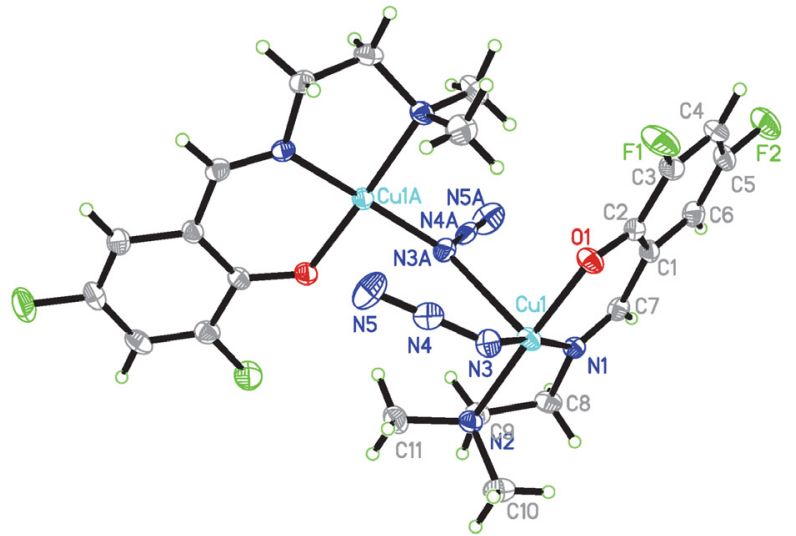

Figure 1. A perspective view of complex 1 with the atom labeling scheme. Thermal ellipsoids are drawn at the $30 \%$ probability level.
The asymmetric unit of the complex contains a $\left[\mathrm{CuL}^{1}(\mathrm{NCS})\right]$ unit. The $\mathrm{Cu}$ atom is coordinated in a square pyramidal geometry, with the phenolate $\mathrm{O} 1$, imino $\mathrm{N} 1$, amino $\mathrm{N} 2$ atoms of the Schiff base ligand $\mathrm{L}^{1}$, and the thio-

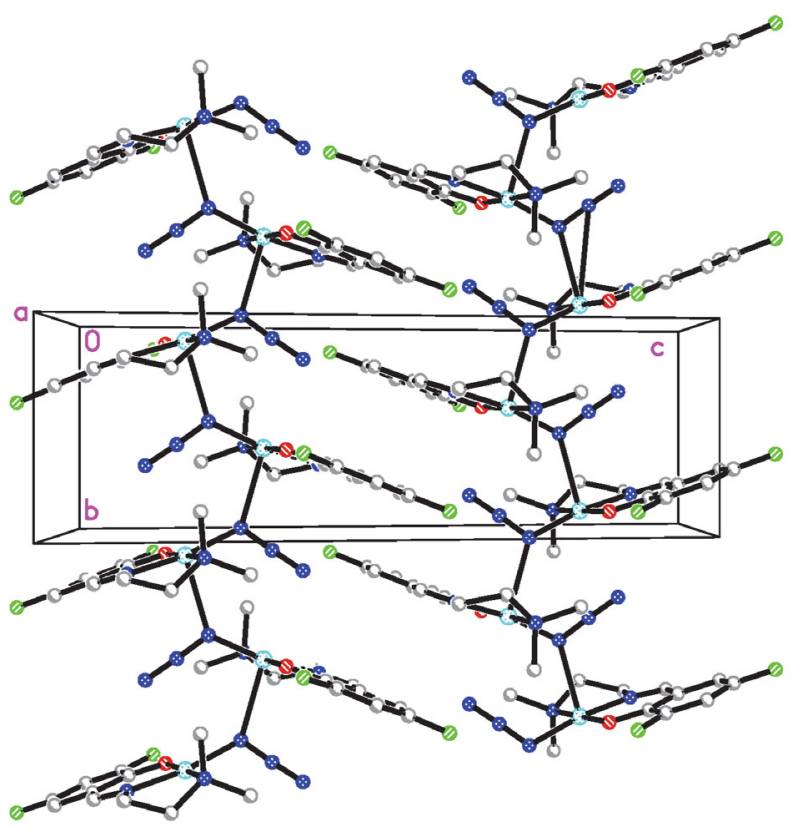

Figure 2. Molecular packing structure of complex 1, viewed along the $b$ axis.

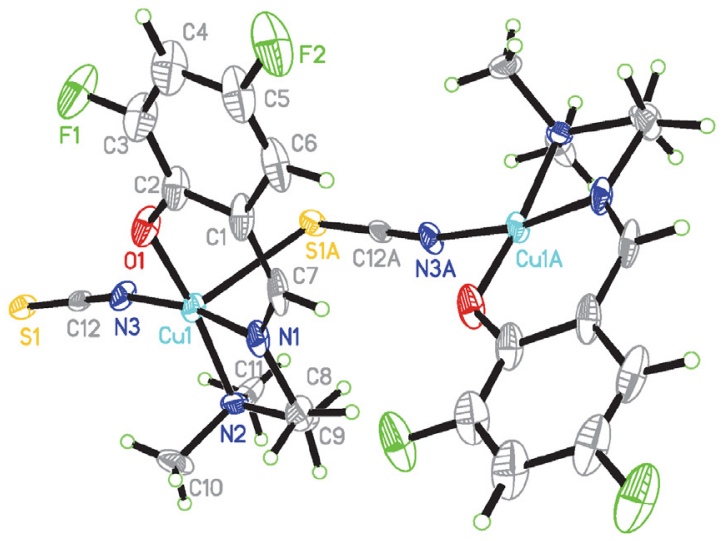

Figure 3. A perspective view of complex 3 with the atom labeling scheme. Thermal ellipsoids are drawn at the $30 \%$ probability level.

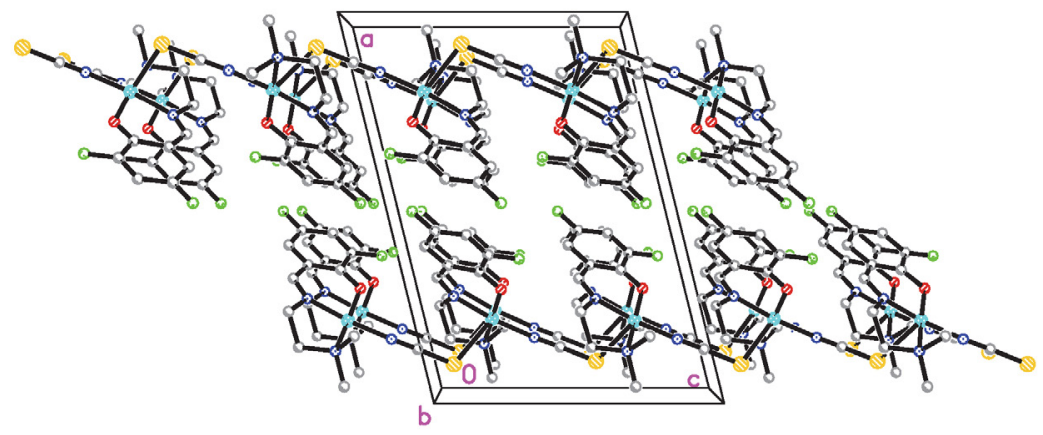

Figure 4. Molecular packing structure of complex 2, viewed along the $c$ axis. 
cyanate $\mathrm{N} 3$ atom defining the basal plane, and with the thiocyanato S1A atom located at the apical position. The Schiff base ligand, acts as a tridentate ligand, chelate the $\mathrm{Cu}$ atom by generating one five and one six-membered rings with bite angles of $84.4(2)^{\circ}$ and $92.1(2)^{\circ}$, respectively. The displacement of the $\mathrm{Cu}$ atom from the plane defined by the four basal donor atoms toward the apical thiocyanato $S$ atom by $0.160(2) \AA$. The thiocyanate ligand bridges $\mathrm{Cu}$ atoms with an end-to-end bridging mode, generating a $\mathrm{Cu} \cdots \mathrm{Cu}$ distance of 6.077(4) $\AA$. The bond lengths and angles in the square pyramidal coordination are similar to those in the reported thiocyanate bridged Schiff base copper complexes. ${ }^{18}$ In the crystal structure of the complex, the $\left[\mathrm{CuL}^{1}\right]$ units are linked by the thiocyanate bridges, to form one-dimensional chains along the $c$ axis (Figure 4).

\section{5. Structure Description of Complex 3}

Molecular structure of the mononuclear copper complex 3 is shown in Figure 5. The complex contains a $\left[\mathrm{Cu}\left(\mathrm{HL}^{2}\right)_{2}\right]^{2+}$ cation and two thiocyanate anions. The molecule possesses crystallographic inversion center symmetry. The $\mathrm{Cu}$ atom, located at the center, is coordinated in a square planar geometry by the phenolate $\mathrm{O} 1$ and $\mathrm{O} 1 \mathrm{~A}$ and imino N1 and N1A atoms. The Schiff base ligand, acts as a bidentate ligand, chelate the $\mathrm{Cu}$ atom by generating one

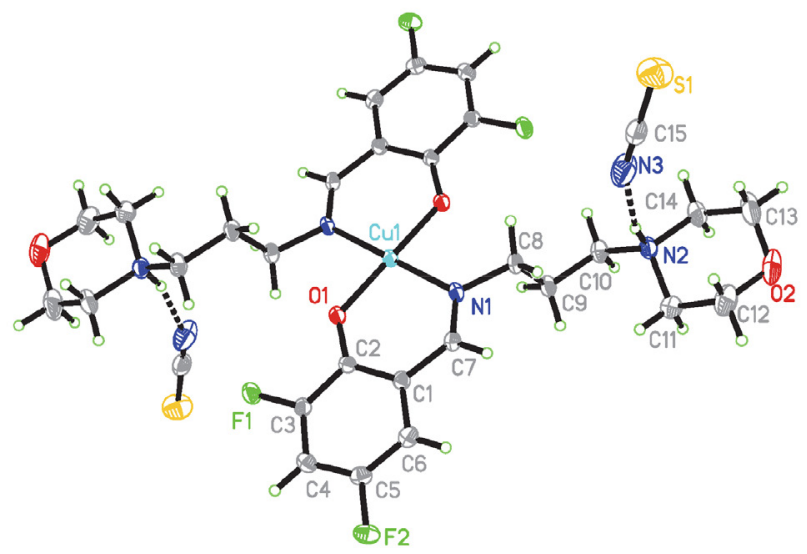

Figure 5. A perspective view of complex 3 with the atom labeling scheme. Thermal ellipsoids are drawn at the $30 \%$ probability level. Hydrogen bonds are shown as dashed lines. six-membered ring with bite angle of $92.3(1)^{\circ}$. The morpholine $\mathrm{N}$ atom is protonated, and forms a hydrogen bond with the thiocyanate anion $(\mathrm{N} 2-\mathrm{H} 2 \cdots \mathrm{N} 3: \mathrm{N} 2-\mathrm{H} 2=0.91 \AA$, $\mathrm{H} 2 \cdots \mathrm{N} 3=1.92 \AA, \mathrm{N} 2 \cdots \mathrm{N} 3=2.806(7) \AA, \mathrm{N} 2-\mathrm{H} 2 \cdots \mathrm{N} 3=$ $\left.165(3)^{\circ}\right)$. The bond lengths and angles in the square planar coordination are similar to those in the reported Schiff base copper complexes. ${ }^{19}$ In the crystal structure of the complex, the molecules are stack along the $a$ axis via weak $\pi \cdots \pi$ interactions (Figure 6).

\section{6. Structure Description of Complex 4}

Molecular structure of the mononuclear copper complex 4 is shown in Figure 7. The complex contains a $\left[\mathrm{Cu}\left(\mathrm{L}^{2}\right)_{2}\right]$ molecule. The molecule possesses crystallographic inversion center symmetry. The $\mathrm{Cu}$ atom, located at the center, is coordinated in a square planar geometry by the phenolate $\mathrm{O} 1$ and $\mathrm{O} 1 \mathrm{~A}$ and imino $\mathrm{N} 1$ and $\mathrm{N} 1 \mathrm{~A}$ atoms. The Schiff base ligand, acts as a bidentate ligand, chelate the $\mathrm{Cu}$ atom by generating one six-membered ring with bite angle of $88.1(1)^{\circ}$. The bond lengths and angles in the square planar coordination are similar to those in the reported Schiff base copper complexes. ${ }^{19}$ In the crystal structure of the complex, the molecules are stack along the $a$ axis via weak $\pi \cdots \pi$ interactions (Figure 8 ).

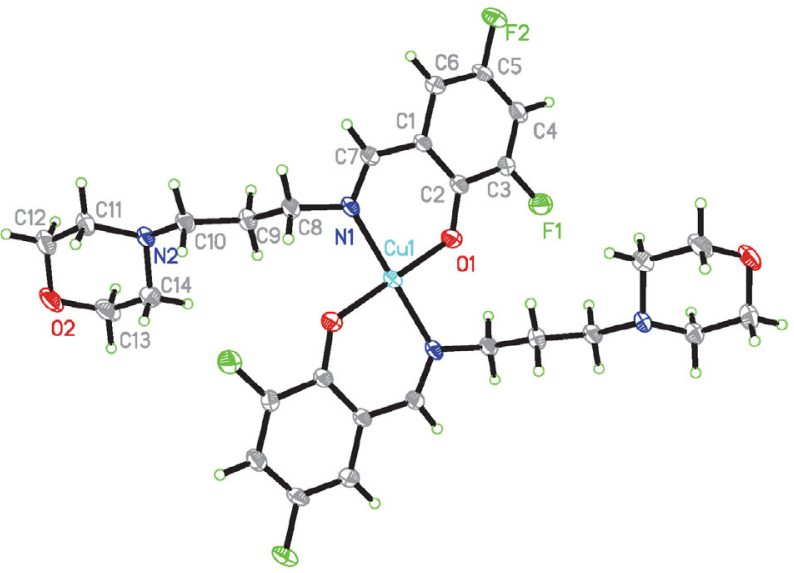

Figure 7. A perspective view of complex 4 with the atom labeling scheme. Thermal ellipsoids are drawn at the $30 \%$ probability level.

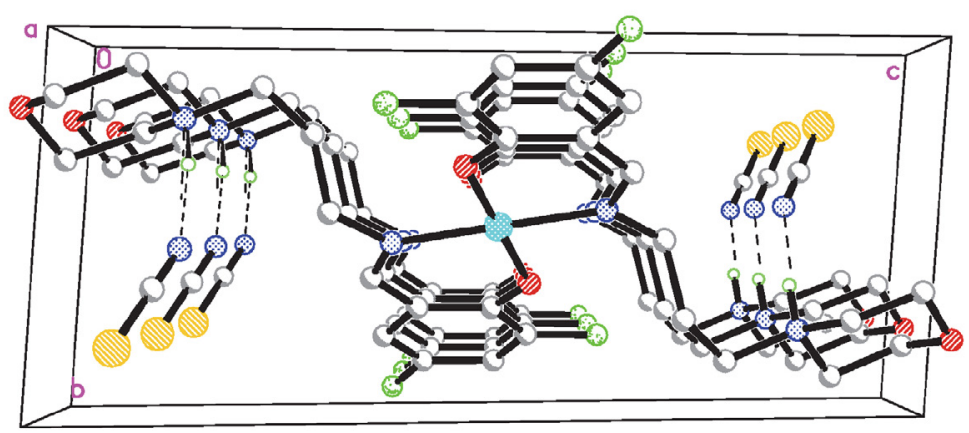

Figure 6. Molecular packing structure of complex 3, viewed along the $a$ axis. Hydrogen bonds are shown as dashed lines. 


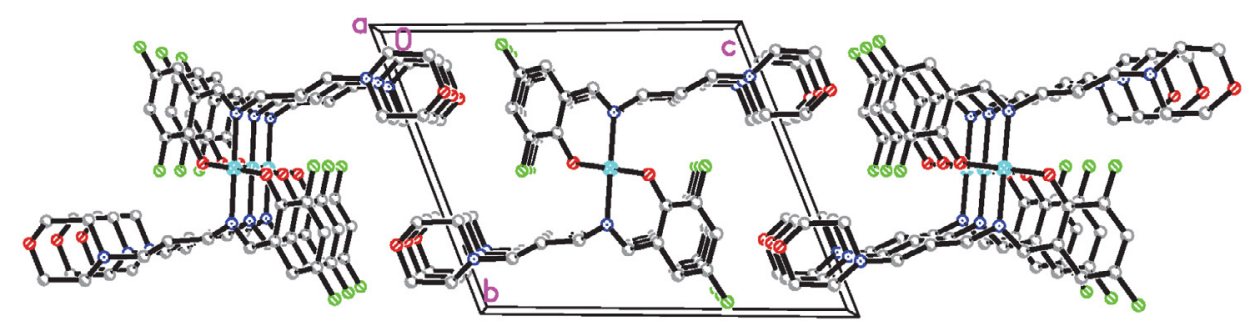

Figure 8. Molecular packing structure of complex 4, viewed along the $a$ axis.

Table 3. Antimicrobial activities of the complexes with minimum inhibitory concentrations $\left(\mu \mathrm{g} \mathrm{mL} \mathrm{m}^{-1}\right)$

\begin{tabular}{ccccc}
\hline Tested material & B. subtilis & S. aureus & E. coli & P. fluorescence \\
\hline 1 & 2.3 & 9.4 & 4.7 & 37.5 \\
2 & 2.3 & 9.4 & 4.7 & 37.5 \\
3 & 1.2 & 2.3 & 9.4 & 75 \\
4 & 1.2 & 2.3 & 9.4 & 75 \\
Penicillin G & 2.3 & 4.7 & $>150$ & $>150$ \\
\hline
\end{tabular}

\section{7. Antimicrobial Activity}

The complexes were screened for antibacterial activities against two Gram (+) bacterial strains (Bacillus subtilis and Staphylococcus aureus) and two Gram (-) bacterial strains (Escherichia coli and Pseudomonas fluorescence) by MTT method. The MIC (minimum inhibitory concentration, $\mu \mathrm{g} \mathrm{mL}^{-1}$ ) values of the compounds against four bacteria are listed in Table 3. Penicillin G was used as the standard drug. Interestingly, complex $\mathbf{1}$ has the same activities against all the bacteria as complex $\mathbf{2}$. And, complex $\mathbf{3}$ has the same activities against all the bacteria as complex 4 . Thus, the azide and thiocyanate ligands or anions in the complexes do not have obvious influence on the antibacterial activity. Complexes $\mathbf{1}$ and $\mathbf{2}$ show strong activity against $B$. subtilis and $E$. coli, and medium activity against $S$. aureus and $P$. fluorescence. Complexes $\mathbf{3}$ and $\mathbf{4}$ show strong activity against $B$. subtilis and $S$. aureus, medium activity against $E$. coli, and weak activity against $P$. fluorescence. The complexes have strong or similar activities against $B$. subtilis, $S$. aureus and E. coli which comparable to Penicillin G. However, all the complexes have no activity on the fungal strains Candida albicans and Aspergillus niger. The antimicrobial activities of the complexes are comparable to the copper complex derived from 2-hydroxy-5-methylbenzaldehyde oxime. ${ }^{20}$

\section{Conclusion}

In summary, an end-on azide bridged polymeric copper(II) complex, an end-to-end thiocyanate bridged polymeric copper(II) complex, and two mononuclear copper(II) complexes derived from the Schiff bases 2-((2-(dimethylamino)ethylimino)methyl-4,6-diluorophenol and 2,4-difluoro-6-((3-morpholinopropylimino)methyl)phenol were obtained. The $\mathrm{Cu}$ atoms in the polymeric complexes are in square pyramidal geometry, and those in the mononuclear complexes are in square planar geometry. One compound has ionic structure $\left(\left[\mathrm{Cu}\left(\mathrm{HL}^{2}\right)_{2}\right]^{2+}\right.$ cation, two thiocyanate anions) in others the molecules are present. The results of the conductivity measurements are in agreement with that determined by the single crystal X-ray analysis. The complexes have strong activities against the bacteria B. subtilis, S. aureus and E. coli.

\section{Supplementary Data}

CCDC 2021453-2021456 (1-4) contain the supplementary crystallographic data for the compounds. These data can be obtained free of charge via http://www.ccdc. cam.ac.uk/conts/retrieving.html, or from the Cambridge Crystallographic Data Centre, 12 Union Road, Cambridge CB2 1EZ, UK; fax: (+44) 1223-336-033; or e-mail: deposit@ccdc.cam.ac.uk.

\section{Acknowledgments}

This work was financially supported by K.C. Wong Magna Fund in Ningbo University, Ningbo Public Fund (Project No. 202002N3056), and the State Key Laboratory Development Fund of Structural Chemistry (Project No. 20190028).

\section{References}

1. (a) M. H. Esfahani, M. Behzad, J. Coord. Chem. 2020, 73, 154-163; DOI:10.1080/00958972.2020.1725492 
(b) K.-C. Gan, K.-M. Sim, T.-M. Lim, K.-C. Teo, Lett. Org. Chem. 2020, 17, 191-198;

DOI: $10.2174 / 1570178616666190724114741$

(c) S. Mandal, T. Sen, U. Mandal, D. Bhunia, C. Rizzoli, D. Bandyopadhyay, J. Coord. Chem. 2019, 72, 3614-3624; DOI:10.1080/00958972.2019.1704275

(d) I. P. Ejidike, P. A. Ajibade, Rev. Inorg. Chem. 2015, 35, 191-224. DOI:10.1515/revic-2015-0007

2. (a) P.-L. Lam, K. K.-H. Lee, S. H.-L. Kok, R. Gambari, K.-H. Lam, C.-L. Ho, X. Ma, Y.-H. Lo, W.-Y. Wong, Q.-C. Dong, Z.X. Bian, C.-H. Chui, RSC Advances 2016, 6, 104575-104581; DOI:10.1039/C6RA20186E

(b) R. K. Mohapatra, A. K. Sarangi, M. Azam, M. M. El-ajaily, M. Kudrat-E-Zahan, S. B. Patjoshi, D. C. Dash, J. Mol. Struct. 2019, 1179, 65-75; DOI:10.1016/j.molstruc.2018.10.070 (c) M. A. Malik, S. A. Lone, P. Gull, O. A. Dar, M. Y. Wani, A. Ahmad, A. A. Hashimi, Med. Chem. 2019, 15, 648-658. DOI:10.2174/1573406415666181203115957

3. (a) N. R. Palepu, S. L. Nongbri, J. R. Premkumar, A. K. Verma, K. Bhattacharjee, S. R. Joshi, S. Forbes, Y. Mozharivskyj, R. Thounaojam, K. Aguan, M. R. Kollipara, J. Biol. Inorg. Chem. 2015, 20, 619-638; DOI:10.1007/s00775-015-1249-3

(b) D. A. Sabbah, F. Al-Tarawneh, W. H. Talib, K. Sweidan, S. K. Bardaweel, E. Al-Shalabi, H. A. Zhong, G. Abu Sheikha, R. Abu Khalaf, M. S. Mubarak, Med. Chem. 2018, 14, 695-708; DOI:10.2174/1573406414666180412160142

(c) A. S. Hassan, H. M. Awad, A. A. Magd-El-Din, T. S. Hafez, Med. Chem. Res. 2018, 27, 915-927;

DOI:10.1007/s00044-017-2113-5

(d) K. Venkateswarlu, N. Ganji, S. Daravath, K. Kanneboina, K. Rangan, Shivaraj, Polyhedron 2019, 171, 86-97.

DOI:10.1016/j.poly.2019.06.048

4. (a) M. Zhang, D.-M. Xian, H.-H. Li, J.-C. Zhang, Z.-L. You, Aust. J. Chem. 2012, 65, 343-350; DOI:10.1071/CH11424

(b) L. Shi, H.-M. Ge, S.-H. Tan, H.-Q. Li, Y.-C. Song, H.-L. Zhu, R.-X. Tan, Eur. J. Med. Chem. 2007, 42, 558-564.

DOI:10.1016/j.ejmech.2006.11.010

5. N. P. Rai, V. K. Narayanaswamy, T. Govender, B. K. Manuprasad, S. Shashikanth, P. N. Arunachalam, Eur. J. Med. Chem. 2010, 45, 2677-2682. DOI:10.1016/j.ejmech.2010.02.021

6. (a) M. Ghosh, M. Layek, M. Fleck, R. Saha, D. Bandyopadhyay, Polyhedron 2015, 85, 312-319;

DOI:10.1016/j.poly.2014.08.014

(b) N. Imani, M. Behzad, H. A. Rudbari, G. Bruno, H. S. Jahromi, A. Khaleghian, J. Coord. Chem. 2015, 68, 2296-2306; DOI:10.1080/00958972.2015.1051476

(c) M. Honarkar Ashna, M. Behzad, M. Salehi, J. Coord. Chem. 2016, 69, 190-198;

DOI:10.1080/00958972.2015.1117073

(d) N. Mahlooji, M. Behzad, H. A. Rudbari, G. Bruno, B. Ghanbari, Inorg. Chim. Acta 2016, 445, 124-128.

DOI:10.1016/j.ica.2016.02.040

7. (a) C.-L. Zhang, X.-Y. Qiu, S.-J. Liu, Acta Chim. Slov. 2019, 66, 719-725; DOI:10.17344/acsi.2019.5241

(b) L.-Y. He, X.-Y. Qiu, J.-Y. Cheng, S.-J. Liu, S.-M. Wu, Polyhedron 2018, 156, 105-110; DOI:10.1016/j.poly.2018.09.017 (c) S. M. Wu, X. Y. Qiu, J. C. Wang, S. J. Liu, L. Y. He, Russ. J. Coord. Chem. 2019, 45, 384-390.

8. Bruker, SMART (Version 5.625) and SAINT (Version 6.01). Bruker AXS Inc., Madison, Wisconsin, USA, 2007.

9. G. M. Sheldrick, SADABS. Program for Empirical Absorption Correction of Area Detector, University of Göttingen, Germany, 1996.

10. G. M. Sheldrick, SHELXTL V5.1 Software Reference Manual, Bruker AXS, Inc., Madison, Wisconsin, USA, 1997.

11. J. Meletiadis, J. F. G. M. Meis, J. W. Mouton, J. P. Donnelly, P. E. Verweij, J. Clin. Microbiol. 2000, 38, 2949-2954. DOI:10.1128/JCM.38.8.2949-2954.2000

12. (a) W. J. Geary, Coord. Chem. Rev. 1971, 7, 81-122; DOI:10.1016/S0010-8545(00)80009-0

(b) G. S. Girolami, T. B. Rauchfuss, R. J. Angelici, Synthesis and technique in inorganic chemistry, a laboratory manual, 3rd edition, University Science Books, Sausalito, 1999, 254.

13. (a) S. S. Massoud, F. A. Mautner, Inorg. Chim. Acta 2005, 358, 3334-3340; DOI:10.1016/j.ica.2005.05.007

(b) A. D. Khalaji, H. Stoekli-Evans, Polyhedron 2009, 28, 3769-3773. DOI:10.1016/j.poly.2009.07.068

14. (a) H. Grove, M. Julve, F. Lloret, P. E. Kruger, K. W. Tornroos, J. Sletten, Inorg. Chim. Acta 2001, 325, 115-124; DOI:10.1016/S0020-1693(01)00642-9

(b) S. Basak, S. Sen, S. Banerjee, S. Mitra, G. Rosair, M. T. Garland Rodriguez, Polyhedron 2007, 26, 5104-5112.

DOI:10.1016/j.poly.2007.07.025

15. Y.-M. Zhou, X.-R. Ye, F.-B. Xin, X.-Q. Xin, Transition Met. Chem. 1999, 24, 118-120. DOI:10.1023/A:1006989707001

16. A. Ray, D. Sadhukhan, G. M. Rosair, C. J. Gomez-Garcia, S. Mitra, Polyhedron 2009, 28, 3542-3550.

DOI:10.1016/j.poly.2009.07.017

17. (a) P. Bhowmik, A. Bhattacharyya, K. Harms, S. Sproules, S. Chattopadhyay, Polyhedron 2015, 85, 221-231;

DOI:10.1016/j.poly.2014.08.021

(b) S. Jana, B. K. Shaw, P. Bhowmik, K. Harms, M. G. B. Drew, S. Chattopadhyay, S. K. Saha, Inorg. Chem. 2014, 53, 8723-8734; DOI:10.1021/ic501353g

(c) P. Mukherjee, M. G. B. Drew, A. Ghosh, Eur. J. Inorg. Chem. 2008, 3372-3381;

DOI:10.1002/ejic.200800186

(d) R. Vafazadeh, A. Kazemi-nasab, A. C. Willis, Acta Chim. Slov. 2019, 66, 1010-1018. DOI:10.17344/acsi.2019.5333

18. (a) P. Bhowmik, S. Chattopadhyay, M. G. B. Drew, A. Ghosh, Inorg. Chim. Acta 2013, 395, 24-32;

DOI:10.1016/j.ica.2012.10.020

(b) Z.-L. You, D.-M. Xian, M. Zhang, CrystEngComm 2012, 14, 7133-7136; DOI:10.1039/c2ce26201k

(c) X.-Y. Qiu, W.-S. Liu, H.-L. Zhu, Z. Anorg. Allg. Chem. 2007, 633, 1480-1484; DOI:10.1002/zaac.200700132

(d) H. Zhao, X.-P. Tan, Q.-A. Peng, C.-Z. Shi, Y.-F. Zhao, Y.M. Cui, Acta Chim. Slov. 2020, 67, 638-643.

DOI:10.17344/acsi.2019.5644

19. (a) C. Senol, Z. Hayvali, H. Dal, T. Hokelek, J. Mol. Struct. 2011, 997, 53-59; DOI:10.1016/j.molstruc.2011.04.037 
(b) M. E. Bluhm, M. Ciesielski, H. Gorls, O. Walter, M. Doring, Inorg. Chem. 2003, 42, 8878-8885;

DOI:10.1021/ic034773a

(c) P. A. N. Reddy, M. Nethaji, A. R. Chakravarty, Inorg.

Chem. Commun. 2003, 6, 698-701;
DOI:10.1016/S1387-7003(03)00090-X

(d) M. Iqbal, A. Mushtaq, S. Ali, M. Sohail, P. A. Anderson, Acta Chim. Slov. 2018, 65, 989-997.

DOI:10.17344/acsi.2018.4695

20. Y.-L. Sang, X.-S. Lin, Acta Chim. Slov. 2019, 66, 168-172.

\section{Povzetek}

Sintetizirali smo štiri nove bakrove(II) komplekse, $\left[\mathrm{CuL}^{1}\left(\mu_{1,1}-\mathrm{N}_{3}\right)\right]_{\mathrm{n}}(\mathbf{1}),\left[\mathrm{CuL}^{1}\left(\mu_{1,3}-\mathrm{NCS}\right)\right]_{\mathrm{n}}(\mathbf{2}),\left[\mathrm{Cu}\left(\mathrm{HL}^{2}\right)_{2}\right](\mathrm{SCN})_{2}(\mathbf{3})$ in $\left[\mathrm{Cu}\left(\mathrm{L}^{2}\right)_{2}\right](4)$, kjer sta L ${ }^{1}$ in L ${ }^{2}$ 2-((2-(dimetilamino)etilimino)metil-4,6-difluorofenolat in 2,4-difluoro-6-((3-morfolinopropilimino)metil)fenolat, $\mathrm{HL}^{2}$ pa je 2-((2-(dimetilammonio)etilimino)metil-4,6-difluorofenolat. Okarakterizirali smo jih z elementno analizo ter IR in UV-vis spektroskopijo. Strukture kompleksov smo potrdili z monokristalno rentgensko difrakcijo. Kompleksa $\mathbf{1}$ in $\mathbf{2}$ sta polimerna bakrova(II) kompleksa s kvadratno piramidalno geometrijo okoli Cu atoma. Kompleksa 3 in 4 sta enojedrna bakrova(II) kompleksa s kvadratno planarno geometrijo okoli Cu atoma. Kompleksom smo določili antimikrobne lastnosti. 